Article

\title{
Capturing the Gender Gap in the Scope of Parenting Related Leave Policies Across Nations
}

\author{
Alison Koslowski \\ School of Social and Political Science, University of Edinburgh, Edinburgh, EH8 9LD, UK; E-Mail: alison.koslowski@ed.ac.uk
}

Submitted: 15 November 2020 | Accepted: 5 February 2021 | Published: 11 June 2021

\begin{abstract}
This article contributes to the conceptual and technical development of cross-national measurement and analysis of the gender gap in the scope of parenting related leave entitlements. That there is a gender gap in the scope of leave benefits is widely acknowledged, but it is rarely quantified. The nomenclature in use around leave policies is diverse and so a first step is to standardise categories and develop a unit of parenting related leave. There is considerable cross-national variation in the configuration of the scope of leave policies. As such, a second step is to consider how best to include the different dimensions of this scope (e.g., duration, payment level, individual parent versus family design) in an estimate of the gender gap in entitlement. Using data collated by the International Network on Leave Policies and Research, a gender gap indicator is created to contribute to our understanding of the inclusiveness of parenting related leave for men as compared to women. This indicator highlights that only two (Iceland and Norway) of 45 countries included in this analysis had achieved a zero-gender gap in terms of entitlement to 'well-paid,' individual parenting related leave during the first 18 months of a child's life. The average gender gap for the countries in the analysis is between two to three months. Only seven countries offered more than two months leave to fathers as an individual entitlement. This is likely to be part of the explanation in many countries for lower leave taking practice by men compared to women.
\end{abstract}

\section{Keywords}

comparative analysis; inclusiveness; gender gap; leave policy; parenting; social rights

\section{Issue}

This article is part of the issue "The Inclusiveness of Social Rights: The Case of Parental Leave Policies" edited by Sonja Blum (University of Hagen, Germany) and Ivana Dobrotić (University of Oxford, UK / University of Zagreb, Croatia).

(C) 2021 by the author; licensee Cogitatio (Lisbon, Portugal). This article is licensed under a Creative Commons Attribution 4.0 International License (CC BY).

\section{Introduction}

Much leave provision has its roots in a heteronormative and maternalistic political context. That is to say, a world which assumes that it is primarily mothers who 'need' leave policy provisions. These policy pathways can be highly resistant to substantial change (e.g., Boling, 2015; Moss \& O'Brien, 2019). As such, it is perhaps not surprising that the difference, or gap, between the amount of days that men spend on leave compared to women, is considerable. This appears to be the case even in countries where much progress has been made towards equal entitlement for all parents to leave (Eydal \& Rostgaard, 2016; Moss, Koslowski, \& Duvander, 2019).

Whilst fathers are less likely than mothers to take parenting related leave, there is variation in leave tak- ing by men across countries, linked to the extent of independent entitlement (Karu \& Tremblay, 2018). Indeed, in some countries, parents may have equal-or near equalentitlement to parenting related leave, which in this case is often referred to as parental leave (see, e.g., Bungum \& Kvande, 2020, for Norway; Schober, Blum, Erler, \& Reimer, 2020 , for Germany). However, in many countries, the gender gap in parenting related leave taking is built into the system explicitly through gendered maternity and paternity leave entitlements (see, e.g., Addabbo, Cardinali, Giovannini, \& Mazzucchelli, 2020, for Italy). That is to say, statutory leave may not be similarly available to (female) mothers and their (male) partners; there is a gender gap in entitlement to parenting related leave.

This article posits that in order to have an accurate picture of the cross-national variation in the gender gap 
in parenting related leaves and take up of such leave, it is necessary to compare not only parental leaves, but all parenting related care leaves. A gender gap exists if there is a difference in a given indicator between women and men (e.g., European Institute for Gender Equality, 2020a). Arguably, equal entitlement to parenting related leaves is a first step in closing the gender gap in their use. As such, a cross-national indicator of this scope of entitlement gender gap can serve as a useful benchmark for scholars and policy makers. Both national governments and a growing number of international bodies have identified measures that can be taken to reduce gender gaps, and it is important to have data and indicators to benchmark and monitor progress towards this goal.

There are various dimensions in the scope of parenting related leave including: duration of leave (linked to the age of the child), payment of leave, whether it is an individual entitlement or a family entitlement and whether it is transferable. These dimensions are all related to gender equality in leave taking practice (Castro-Garcia \& Pazos-Moran, 2015; Ciccia \& Verloo, 2012; Ray, Gornick, \& Schmitt, 2010). All these factors should be taken into account in the development of a unit of comparison for a gender gap in parenting related leave entitlement. Due to the gender focus as well as country level differences in entitlement for non-heterosexual biological and adoptive parents, the focus of this research is not on these groups. This article aims to contribute to leave scholarship by proposing a gender gap indicator of 'well-paid,' individual entitlement to parenting related leave during the first 18 months of a child's life.

\section{Understanding the Gender Gap in Parenting Related Leave}

With a few exceptions, much leave policy design presupposes a primary carer model, which whilst potentially couched in gender neutral terms, remains synonymous with a mother-centric approach to infant care (e.g., see discussion in Kaufman, 2020). A leave system which assumes a primary carer, presupposes the breadwinner/carer model, just without the explicit assumption that the carer is female. These systems may aim to enable mothers to remain in the labour market, but they do not seek to shift the division of caring work. Gender equality can potentially have different interpretations in terms of leave provision. Countries could maintain a primary carer model and still claim gender equality in the case that leave provision and take up (and corresponding breadwinners) were evenly distributed by gender (e.g., see discussion in Koslowski \& Duvander, 2018). An even distribution of breadwinners and/or primary carers by gender has not yet been observed in any country. A more certain route towards gender equality in parenting is arguably to legislatively support co-parenting (Kaufman, 2020). Co-parenting sees reduced specialisation between parents, with both actively engaged as carers and actively engaged in paid work as required, when not on leave.
Thus, intended policy outcomes related to gender equality for leave policies vary. Some policy making bodies have promoted them as a key instrument for maintaining the presence of mothers in the labour market (as discussed in Ciccia \& Verloo, 2012; Dearing, 2016; Pronzato, 2009). Other policy actors have also seen them as a key instrument for increasing the opportunities for fathers to spend more time caring for their young children in addition to maintaining mothers' labour market participation (Caracciolo di Torella, 2014; O'Brien, 2009). Leave policies can also be important policy instruments for supporting child health and well-being, maternal and paternal health and well-being, fertility rates, and for addressing gender pay gaps (Andersen, 2018; Thévenon, 2011).

\subsection{Parenting Related Leave}

Parents may be entitled to a range of different types of statutory leave (usually from their workplace), but the focus here is on leave dedicated to the care of infants. Different countries use a range of different terms to refer to the various leaves. There is not an entirely standard nomenclature. The most common terms for parenting-related leave are maternity leave, paternity leave, parental leave and birth leave (see Koslowski, Blum, Dobrotić, Kaufman, \& Moss, 2020). This list of terms is not exhaustive, there are other terms (e.g., family leave, primary carer leave, childcare leave). Annual leave and sickness leave are also sometimes used by parents in order to care for infants. Some countries also offer specific leaves to allow parents to care for children who are ill (Bartel, Rossin-Slater, Ruhm, Stearns, \& Waldfogel, 2018; Koslowski et al., 2020), but these are not included in this analysis. Whilst these leaves can be an extremely important source of support for parents and linked to gender equality outcomes, the focus of this article is on the care leaves available to parents with infants in their first 18 months.

Maternity leave is usually specific to the birth mother, though in some cases can be transferred to another person, usually the father. Paternity leave is usually specific to the father or in some countries, also for another (e.g., same sex) co-parent, usually to be taken soon after the birth of a child. It is often quite short term (a couple of days to a few weeks duration). Parental leave is generally understood to be a longer term care measure for infants, intended to give both parents (and sometimes other parties) the opportunity to spend time caring for a young child (and for the infant to be cared for by its parents); it can usually only be taken at the end of maternity leave (see Koslowski et al., 2020). It is usual for the leave available to adoptive parents to be similar in configuration to the other leave provision available in a country.

Many studies choose to focus on either maternity, paternity or parental leave, but rarely all of these in the same article. Whilst this is often a sound approach for the research questions at hand, to only focus on parental 
leave when the goal is to estimate the gender gap in entitlement to leave is likely to lead to an under-estimation of the size of the gender gap, particularly in countries with a longer gender-specific birth-related leave for mothers (usually referred to as maternity leave). For example, in Ireland, women may have access to 42 weeks maternity leave, compared to men having two weeks paternity leave, in addition to equal entitlement to 18 weeks of parental leave (Daly \& Szelewa, 2020). In Hungary, women may have access to 24 weeks maternity leave, compared to men having five days paternity leave, in addition to equal (family) entitlement to parental leave after the maternity leave period (Gábos \& Makay, 2020). A first step is to map the various leaves, noting their nomenclature, but also their characteristics, as sometimes similar terms can be used differently across countries, as seen in the annual reviews of the International Network of Leave Policies and Research (e.g., Koslowski et al., 2020). The next step is to operationalise a standardised unit of leave in order to estimate a gender gap in entitlement to leave. Is all leave to be considered equivalent, or is it that only well-paid leave to which an individual is entitled is leave that is likely to be accessible to (all) parents in practice (Ray et al., 2010).

Leave policies are particularly relevant to working parents with dependent children, though eligibility to them may extend beyond this more narrowly defined group, such as to grandparents (see, e.g., Dimitrova, Kotzeva, \& Ilieva, 2020, for Bulgaria) or other close person if the second parent is unknown (see, e.g., Duvander \& Löfgren, 2020, for Sweden). Much leave policy has been developed from a heteronormative and biological parenting assumption. However, in recent years, the legal possibilities to become a parent have become broader in some countries and this can change the population of people with entitlement to leave policies (Digoix, 2020). This article considers the gender gap in the population of parents of infants and the understanding of 'parent' rests with the legal definitions in a given country at the time of data collection, April 2020. In addition to any gender gap, there may also be many parents who are not eligible for leave provisions (Dobrotić \& Blum, 2020) and this may add an additional element to the gender gap in entitlement to leave.

\subsection{What is Being Compared?}

No single country has designed the scope of its leave provisions in quite the same way as any other country (Koslowski et al., 2020), which creates challenges for the standardisation required for measurement. At their most basic, statutory leave policies usually provide job protection for a period of time so that a worker can be available to care for a dependant and after this period of time, return to employment with the same employer (and usually the same job). They can also include an element of wage replacement during this period (Ray et al., 2010). Indeed, much of the evidence suggests that leave being 'well-paid' is a crucial element of the scope of benefit for gender equal outcomes. 'Well-paid' is understood in various ways by different groups of scholars. Some would argue that for leave to be 'well-paid' and thus a viable option for many parents, it should be 100 percent wage replacement. In practice, a threshold that is often used in comparative literature is 66 percent wage replacement (e.g., Koslowski et al., 2020; Ray et al., 2010).

To further complicate matters for comparative analysis, some parents are eligible for 'top ups' to statutory entitlement from their employers (Koslowski \& Kadar-Satat, 2019), as a result of collective agreements (e.g., Sweden, Netherlands; see den Dulk, Yerkes, \& Peper, 2018), or as part of a package of occupational benefits (e.g., offered by international companies such as Aviva, Diageo, and Proctor \& Gamble). Whilst such occupational or extra-statutory leave provision can play an important role for many parents, and in some cases may also be far more de-gendered than statutory provision (see, e.g., Kaufman, 2020), it can be very difficult to obtain sufficient data on such arrangements for cross-national or even national analysis (e.g., Koslowski \& Kadar-Satat, 2019). As such, this article joins much of the literature by maintaining the focus on statutory leaves. In some countries (e.g., Greece, Malta, Uruguay), there are different statutory regimes for the public and private sectors (Koslowski et al., 2020), so a decision is required as to which regime to include in cross-national work. In addition, there may be regional differences to statutory legislation (e.g., Belgium, Canada). As such, the amount of leave (in terms of benefit payments and duration) available to (some) parents in a country is likely to be underestimated, but this does not negate the utility in mapping the baseline entitlements.

Parenting is not usually an aspect of life that is experienced solely at the level of the individual, rather at the level of the household (or family), and sometimes beyond the household, particularly in the case of lone parents. However, to elucidate the gender gaps, analysis at the individual level is needed. Leave can be 'equally' available to mothers and fathers in different constructs either as (1) a non-transferable individual right, (2) an individual right that can be transferred to the other parent, or (3) a family right that parents divide between themselves (or sometimes between themselves and other family members) as they choose. Of these, it is the former-a non-transferable individual right-that is associated with a reduction in gendered practice as fathers' access to individual entitlement is strongly associated with increased take up of the leave (e.g., Duvander \& Johansson, 2012; Haas \& Rostgaard, 2011; Karu \& Tremblay, 2018), though this design needs to be complemented by sustained political work and cultural change as well for this effect to be realised (e.g., Boling, 2015). In most countries, there are some gender specific elements of leave, but the proportion of total leave available to parents which is gender neutral varies considerably (as shown in Table 1). 
As mentioned above, the various dimensions of leave policy benefit and scope have their own particular associations with gender equal outcomes. This article focuses on leaves relevant for the care of infants (from birth to 18 months) as the gender gap is particularly acute during this phase in the child's life when care is perhaps at its most intensive. (It is also common for mothers to have access to pre-birth leave, which is sometimes compulsory). Fathers spending time caring alone for children during this period for a certain duration is associated with their increased participation in childcare throughout childhood. Thus, as infant care is no longer seen as the sole domain of women, gender equality outcomes follow, such as increased female labour market participation, reduced gender pay gap, and increased male household work participation (Andersen, 2018; Doucet \& McKay, 2020; O’Brien \& Wall, 2017).

Duration of statutory leave periods vary considerably across countries, from periods of days or weeks to years. Moderate durations of leave for women have a large positive effect on women's employment outcomes and working hours, whereas very short and very long leaves are associated with reduced female labour market participation (e.g., Dearing, 2016). Extending durations of leave for men changes how they might negotiate and navigate care and domestic work (treated as a category distinct from care and paid work responsibilities; see Doucet \& McKay, 2020; O’Brien \& Wall, 2017). There is not absolute agreement in the literature about the optimal leave duration (from either parent or child perspective; see Olivetti \& Petrongolo, 2017), but for the purposes of this analysis less than four months would generally be considered as short, from five months to 12 months as moderate, 12 months to two years as long, and more than two years as very long. Increased duration of leave taken by men could contribute to moderate duration leave taking by women (European Institute for Gender Equality, 2021). Duration of leaves impacts employers differently in terms of whether replacement cover is considered feasible, which can also impact on leave taking practice (Pettigrew, 2020). Some countries offer incentives to encourage take up of leave by fathers: For example, the parenting couple may be eligible for extended duration and the associated payment of leave if fathers take a certain amount of parental leave (e.g., in Austria, Croatia, France, Germany, Italy, Portugal; see Koslowski et al., 2020).

There is also considerable cross-national variation in levels of payment to parents during leave, also sometimes within a particular leave episode for an individual parent within a given country context (e.g., UK statutory maternity leave, which is 'well-paid' for six weeks and then drops to a very low flat rate, well below the minimum wage, before ending in an unpaid period; see Atkinson, O'Brien, \& Koslowski, 2020). This UK example illustrates that leave can be unpaid, paid at a low flat rate similar to social assistance, or paid as a form of wage related maintenance. Sometimes a seemingly wage related maintenance system becomes similar to a low flat rate if ceilings are not uprated (e.g., in Croatia; see Dobrotić, 2020). Sometimes, the level of payment varies according to the duration of leave taken, with a number of options available (e.g., in Poland; see Kurowska, Michoń, \& Godlewska-Bujok, 2020). Leave paid as wage-related maintenance is associated with increased uptake by all parents, but in particular by fathers (e.g., Ray et al., 2010).

Another problem for comparisons across countries is that not all parents, or even all working parents are eligible for leave provisions of any nature-or eligible for leave provisions with higher benefit levels. Thus, a crucial aspect of leave policy design is that of how eligibility is determined (e.g., is there a minimum qualifying period of employment, are the self-employed included, are same-sex parents included; see Dobrotić \& Blum, 2020). The aim of this article is to develop an indicator for the gender gap in entitlement across all leaves relating to the first 18 months of a child's life, which can then be included in analysis of eligibility for leave to get the full picture.

\section{Methodology: Operationalizing the Gender Gap in Entitlement to Parenting-Related Leave Benefits}

In light of the discussion above, this article suggests a focus on access to (well) paid leave via an individual entitlement. This builds on the assumption that in addition to legislative entitlement, leave taking can only be realised by many parents when the entitlement is inclusive of compensation for the loss of income from paid work. There is disagreement over what might be considered sufficient compensation for the loss of income from paid work to render leave taking to be fully viable by both parents. As discussed, whilst the distinction between paid and unpaid leave is unambiguous, what constitutes 'well-paid' leave is less clear. For the purposes of this article, the current standard operationalisation of 66 percent for 'well-paid' is used, though it is noted when leave is at the 100 percent level.

As such, data are compiled in Table 1, using one of the cross-national tables in the 2020 Leave Review (Koslowski et al., 2020) so that column (a) indicates wellpaid leave that is available to the family. Technically, this leave is available to either parent, not specifically to either the father or the mother. However, as discussed above, this leave is most often taken by the mother. In some cases, leave shown here can be transferred between parents where there is mutual agreement. This is exclusive of parent-specific leaves mentioned in columns (b) and (c). In some cases, leave is an individual entitlement, but the payment is a family entitlement and, so, this is considered as leave available to the family and not to a specific parent. Column (b) indicates the period of 'father-only' (including other non-birth parents) well-paid leave. This includes paternity leaves but also non-transferable individual entitlements to parental 
leave, including sharing bonuses. Column (c) indicates the period of 'mother-only' well-paid leave, which is usually for the birth mother. This includes maternity leave and non-transferable elements of parental leave.

Data are all taken from the open access 45 country notes and cross-national tables in the International Review of Leave Policies and Research 2020 (Koslowski et al., 2020). The gap is estimated for all 45 countries included in the review, plus Québec, so 46 units of observation (see Table 1 for the full list). A limitation of this research is the reliance on a single data source compiled by multiple contributors.

Only post-birth leave is included in this table (so not pre-birth leave). As noted:

As parents may take some of this leave concurrently, the total amounts do not indicate the child's precise age at the end of well-paid leave. In some countries, it may be possible to take longer leaves, but at a lower payment, and this is not indicated in this table. A month is calculated to be 4.3 weeks; while 4 weeks would be 0.9 months. \# indicates a ceiling on payments. Where there is 100 percent wage replacement rate, this is indicated. (Koslowski et al., 2020, pp. 71-72)

\section{Results: The Gender Gap in Entitlement to Leave (April 2020 for 45 countries)}

Table 1 presents data from a table in the 2020 Leave Review (Koslowski et al., 2020, p. 73) introducing a new column with the calculation of the gender gap indicator in entitlement. Scanning column (a) reveals the variation in availability of well-paid leave as a family entitlement, ranging from 'zero months' in many countries to 24 months in Hungary (though with a ceiling on the maximum payment). This variation is not currently reflected in the proposed gender gap indicator. Technically, this leave would be available to either mother or father, though it is rare in practice that fathers take the leave (Gábos \& Makay, 2020).

Some countries do not have any well-paid leave available to parents, as such, there is technically no gender gap, but this is not considered a positive solution to the

Table 1. Total amount of 'well-paid' leave available to parents in first 18 months of a child's life (April 2020 for 45 countries, plus Québec).

\begin{tabular}{|c|c|c|c|c|}
\hline Country & $\begin{array}{l}\text { (a) Well-paid leave } \\
\text { available as family } \\
\text { entitlement (months) }\end{array}$ & $\begin{array}{l}\text { (b) Period of } \\
\text { 'father-only' well-paid } \\
\text { leave (months) }\end{array}$ & $\begin{array}{l}\text { (c) Period of } \\
\text { 'mother-only' well-paid } \\
\text { leave (months) }\end{array}$ & $\begin{array}{l}\text { Gender gap indicator } \\
\text { in entitlement }\end{array}$ \\
\hline Australia & 0 & 0 & 0 & $\mathrm{n} / \mathrm{a}$ \\
\hline Austria & 12 & $\begin{array}{l}2 \text { (extra parental } \\
\text { leave) }\end{array}$ & 1.9 (100\% earnings) & -0.1 \\
\hline Belgium & 0 & $0.45 \#$ & 3.3 & 2.85 \\
\hline Brazil & 0 & 0.2 or 0.9 & 4 or 6 (private or public) & 3.8 or 5.1 \\
\hline Bulgaria & 0 & $0.5 \#$ & $\begin{array}{l}12 \text { \# (with possibility } \\
\text { to transfer } 6 \text { months } \\
\text { to father) }\end{array}$ & 11.5 \\
\hline Canada & 0 & 0 & 0 & $\mathrm{n} / \mathrm{a}$ \\
\hline Québec & $\begin{array}{l}1.6 \text { to } 5.8 \\
\text { ( } 7 \text { to } 25 \text { weeks) }\end{array}$ & $\begin{array}{l}0.69 \text { to } 1.15 \\
\text { ( } 3 \text { to } 5 \text { weeks) }\end{array}$ & $\begin{array}{l}3.5 \text { to } 4.2 \\
\text { (15 to } 18 \text { weeks) }\end{array}$ & 2.81 to 3.05 \\
\hline Chile & 0 & 1.15 & 5.5 & 4.35 \\
\hline China & 0 & 0.2 to 1 & 2.7 & 1.7 to 2.5 \\
\hline Croatia & $\begin{array}{l}4 \text { (with both parents' } \\
\text { agreement) \# (low; } \\
100 \% \text { earnings) }\end{array}$ & $\begin{array}{l}2 \text { \# (low; } \\
100 \% \text { earnings) }\end{array}$ & $\begin{array}{l}8 \text { ( } 6 \text { with } 100 \% \\
\text { earnings and no } \\
\text { ceiling, then } 2 \text { with \#; } \\
\text { low) }\end{array}$ & 6 \\
\hline Cyprus & 0 & 0.45 & 3.7 & 3.25 \\
\hline Czech Republic & $\begin{array}{l}6 \text { \# (leave is an } \\
\text { individual entitlement } \\
\text { but only one parent } \\
\text { at a time is entitled } \\
\text { to the benefit) }\end{array}$ & $0.2 \#$ & $5.1 \#$ & 4.9 \\
\hline
\end{tabular}




\begin{tabular}{|c|c|c|c|c|}
\hline Country & $\begin{array}{l}\text { (a) Well-paid leave } \\
\text { available as family } \\
\text { entitlement (months) }\end{array}$ & $\begin{array}{l}\text { (b) Period of } \\
\text { 'father-only' well-paid } \\
\text { leave (months) }\end{array}$ & $\begin{array}{l}\text { (c) Period of } \\
\text { 'mother-only' well-paid } \\
\text { leave (months) }\end{array}$ & $\begin{array}{l}\text { Gender gap indicator } \\
\text { in entitlement }\end{array}$ \\
\hline Denmark & $\begin{array}{l}7.4 \# \text { (leave is an } \\
\text { individual entitlement, } \\
\text { but the benefit is a } \\
\text { family entitlement) } \\
\text { (100\% earnings) }\end{array}$ & $\begin{array}{l}0.45 \text { \# (100\% earnings) } \\
\text { Collective agreements } \\
\text { do include provision } \\
\text { for well-paid } \\
\text { 'father-only' leave }\end{array}$ & 3.3 \# (100\% earnings) & 2.85 \\
\hline Estonia & $\begin{array}{l}14.5 \# \\
\text { (100\% earnings) }\end{array}$ & $\begin{array}{l}0.45 \# \\
\text { (100\% earnings) }\end{array}$ & $\begin{array}{l}3.7 \\
\text { (100\% earnings) }\end{array}$ & 3.25 \\
\hline Finland & $6.2 \#$ & $2 \#$ & 2.9 & 0.9 \\
\hline France & 0 & $\begin{array}{l}0.45 \text { (\# in private sector; } \\
100 \% \text { earnings) }\end{array}$ & 3.3 (\# in private sector) & 2.85 \\
\hline $\begin{array}{l}\text { Germany (leave } \\
\text { is paid at a } \\
\text { replacement } \\
\text { rate of } \\
\text { between } 65 \\
\text { and } 67 \% \text { ) }\end{array}$ & $12 \#$ & 2 & 1.9 (100\% earnings) & -0.1 \\
\hline Greece & $\begin{array}{l}\text { Private sector } 3.6 \\
\text { (100\% earnings) } \\
\text { Public sector } 9 \\
\text { (100\% earnings) } \\
\text { (childcare leave } \\
\text { rather than } \\
\text { parental leave) }\end{array}$ & $\begin{array}{l}0.1 \text { ( } 2 \text { days; } \\
100 \% \text { earnings; both } \\
\text { private and public) }\end{array}$ & $\begin{array}{l}\text { private sector: } 2 \# \\
\text { (100\% earnings) } \\
\text { public sector: } 3 \\
\text { (100\% earnings) }\end{array}$ & 1.9 or 2.9 \\
\hline Hungary & $24 \#$ & 0.2 (100\% earnings) & 5.6 & 5.4 \\
\hline Iceland & $2 \#$ & $4 \#$ & $4 \#$ & 0 \\
\hline Ireland & 0 & 0 & 0 & $\mathrm{n} / \mathrm{a}$ \\
\hline Israel & 0 & $\begin{array}{l}0.14 \text { ( } 3 \text { days; } \\
100 \% \text { earnings) }\end{array}$ & 3.5 \# (100\% earnings) & 3.36 \\
\hline Italy & 0 & $\begin{array}{l}0.25 \text { ( } 7 \text { days; } \\
\text { (100\% earnings) }\end{array}$ & 4.7 & 4.45 \\
\hline Japan & 0 & $6 \#$ & $7.9 \#$ & 1.9 \\
\hline Korea & $\begin{array}{l}6 \text { (if } 3 \text { months } \\
\text { taken by second } \\
\text { parent) }\end{array}$ & $\begin{array}{l}3 \text { months parental } \\
\text { leave \# (100\% earnings) } \\
+0.14 \text { ( } 3 \text { days) } \\
\text { paternity leave } \\
\text { (100\% earnings) }\end{array}$ & $\begin{array}{l}3 \text { maternity \# } \\
(100 \% \text { earnings) } \\
+3 \text { parental \# }\end{array}$ & 2.86 \\
\hline Latvia & 0 & 0.33 & 1.9 & 1.57 \\
\hline Lithuania & $12 \#$ & $\begin{array}{l}0.9 \# \\
\text { (77.58\% earnings) }\end{array}$ & $\begin{array}{l}1.9 \\
\text { (77.58\% earnings) }\end{array}$ & 1 \\
\hline Luxembourg & 0 & 4 & $\begin{array}{l}2.8 \text { maternity \# (high) } \\
100 \% \text { earnings } \\
+4 \text { parental }\end{array}$ & 2.8 \\
\hline Malta & 0 & $\begin{array}{l}0.05 \text { ( } 1 \text { day private/ } \\
5 \text { days public (both } \\
\text { sectors } 100 \% \text { earnings) }\end{array}$ & 3.3 (100\% earnings) & 3.25 \\
\hline
\end{tabular}




\begin{tabular}{|c|c|c|c|c|}
\hline Country & $\begin{array}{l}\text { (a) Well-paid leave } \\
\text { available as family } \\
\text { entitlement (months) }\end{array}$ & $\begin{array}{l}\text { (b) Period of } \\
\text { 'father-only' well-paid } \\
\text { leave (months) }\end{array}$ & $\begin{array}{l}\text { (c) Period of } \\
\text { 'mother-only' well-paid } \\
\text { leave (months) }\end{array}$ & $\begin{array}{l}\text { Gender gap indicator } \\
\text { in entitlement }\end{array}$ \\
\hline Mexico & 0 & 0.2 (100\% earnings) & 2.3 (100\% earnings) & 2.1 \\
\hline Netherlands & 0 & 0.2 (100\% earnings) & $2.8 \#$ (100\% earnings) & 2.6 \\
\hline New Zealand & 5.1 \# (100\% earnings) & 0 & 0 & $n / a$ \\
\hline Norway & $\begin{array}{l}4.2(80 \% \text { earnings; } \\
\text { or } 3.7 \text { at } 100 \%)\end{array}$ & $\begin{array}{l}4.4 \text { (80\% earnings; } \\
\text { or } 3.4 \text { at } 100 \%)\end{array}$ & $\begin{array}{l}4.4 \text { (80\% earnings; } \\
\text { or } 3.4 \text { at } 100 \%)\end{array}$ & 0 \\
\hline Poland & $\begin{array}{l}7.4 \text { ( } 80 \% \text { earnings; } \\
\text { may be lower if takes } \\
\text { higher paid maternity } \\
\text { leave option\#) }\end{array}$ & 0.5 (100\% earnings) & $\begin{array}{l}4.6 \text { ( } 80 \% \text { earnings; } \\
100 \% \text { earnings possible } \\
\text { but lower parental } \\
\text { leave payment \#) }\end{array}$ & 4.1 \\
\hline Portugal & $\begin{array}{l}4.6 \text { ( } 80 \% \text { earnings; } \\
\text { or } 3.6 \text { at } 100 \% \text {; } \\
\text { includes sharing } \\
\text { bonus } \#)\end{array}$ & 1.2 (100\% earnings) & $\begin{array}{l}1.4(100 \% \text { earnings } \\
\text { possible) }\end{array}$ & 0.2 \\
\hline Romania & 23 & $\begin{array}{l}0.4 \text { ( } 100 \% \text { earnings) } \\
\text { plus } 1 \text { sharing bonus }\end{array}$ & 4.2 & 3.8 \\
\hline Russia & 0 & 0 & 2.3 (100\% earnings) & 2.3 \\
\hline Slovakia & 0 & 0 & $6.5 \#$ & 6.5 \\
\hline Slovenia & 7.6 \# (100\% earnings) & 1 \# (100\% earnings) & 3.6 (100\% earnings) & 2.6 \\
\hline South Africa & 0 & 0.45 & 0 & -0.45 \\
\hline Spain & 0 & 2.8 \# (100\% earnings) & 3.7 \# (100\% earnings) & 0.9 \\
\hline Sweden & $\begin{array}{l}9.8 \text { \# (transferable } \\
\text { parental leave) }\end{array}$ & $3.3 \#$ & $3 \#$ & -0.3 \\
\hline Switzerland & 0 & 0 & $3.3 \#$ & 3.3 \\
\hline United Kingdom & 0 & 0 & 1.4 & 1.4 \\
\hline USA & 0 & 0 & 0 & $\mathrm{n} / \mathrm{a}$ \\
\hline Uruguay & 0 & $\begin{array}{l}\text { public sector, } \\
0.45 \text { months; private } \\
\text { sector, } 10-13 \text { days } \\
\text { (100\% earnings) }\end{array}$ & $\begin{array}{l}\text { public sector, } \\
3.1 \text { months; private } \\
\text { sector, } 3.3 \text { months } \\
\text { (100\% earnings) }\end{array}$ & 2.65 \\
\hline
\end{tabular}

Notes: This table further develops the table in the 2020 Leave Review (Koslowski et al., 2020, p. 73). \# indicates a ceiling.

gender gap in parenting leave entitlement and so, their gender gap is recorded as 'not available,' and these countries are not included in the analysis.

Table 2 shows that the average gender gap over the 41 countries included in the analysis is 2.72 months. The largest gender gap of 11.5 months is found in Bulgaria, which is driven by the long and relatively generous maternity leave duration (see Table 1 ).

Table 3 presents country groupings according to a gender gap indicator index from 1 to 8 , with a score of 1 indicating the smallest gender gap and 8 the largest (a score of 9 indicates a lack of individual well-paid entitlement). The country groupings do not correspond to usual welfare regime groups, but they do make sense in terms of approach to leave policy design. The coun- tries which score lowest on the gender gap indicator index (1 and 2), with the exception of South Africa are all countries which can be said to have given gender equality explicit consideration in the design of their leave policies. As can be seen from Table 1, only two countries can claim to have no gender gap in individual entitlement to well-paid leave: Iceland and Norway. Iceland has the same individual non-transferable entitlement of four months available for fathers and mothers. However, the Icelandic case still cannot be said to be entirely equal as the additional two months transferable element of the benefit entitlement is overwhelmingly taken by mothers. So, even a 0 by this measure does not indicate that the leave design delivers entirely gender equal outcomes. 
Table 2. Descriptive statistics for the gender gap indicator in parenting related leave (months).

\begin{tabular}{lc}
\hline Mean & 2.71 \\
Standard deviation & 2.22 \\
Range & 11.95 \\
Minimum & -0.45 \\
Maximum & 11.5 \\
Count & 41
\end{tabular}

Notes: Five countries (Québec brings the total number of observations to 46) included in Table 1 did not have any individual well-paid leave. Where there were two possible estimates of the gender gap in Table 1 (e.g., Brazil), the lower estimate is included in these descriptive statistics. A negative gender gap indicates that fathers had more individual entitlement than mothers.

Four countries have small negative gender gaps of less than two weeks (Austria, Germany, Sweden, and South Africa), that is to say that fathers have more individual entitlement to well-paid leave. Portugal has a small positive gender gap of less than two weeks, with mothers having slightly more entitlement to leave. Portugal is not one of the usual 'nordic' countries associated with gender equal policy design, but has explicitly designed its parental leave scheme to encourage usage by the fathers (Wall, Correia, \& Leitão, 2020). Similarly, Germany's parental leave design underwent an overhaul in the past decade, and this is reflected here (Bünning, 2015; Schober et al., 2020). The small gap in South Africa is an anomaly and reflects that only fathers have a two week well-paid leave, in contrast to mothers not having any well-paid leave at all. This anomaly highlights the need to ask how the gender gap indicator calculated here is related to the length of well-paid leave provided to fathers (see Figure 1).

Keys to index are as follows:

$1=$ No gender gap or one that is less than two weeks (resulting in either a negative or positive gender gap)

$2=$ The gender gap is between two weeks and less than one month

3 = The gender gap is between one and less than two months
$4=$ The gender gap is between two and less than three months

5 = The gender gap is between three and less than four months

6 = The gender gap is between four and less than five months

7 = The gender gap is between five and less than seven months

$8=$ The gender gap is longer than seven months

$9=\ln$ these countries, there is no individual entitlement to well-paid leave for either mothers or fathers. Thus, these countries are not included in analysis

Caution needs to be applied as we approach the score of 3 . In this grouping of countries, the lower score is associated with a generally lower level of provision for well-paid leave for both mothers and fathers (for example in the UK, which only offers six weeks well-paid leave to mothers), and then mothers and fathers are only equal in terms of the lack of access to an individual entitlement to well-paid leave. Those countries with a score of 4 which represents the average gender gap of between two and three months have the most diverse policy stories. In some cases, there is relatively short entitlement for fathers but also a comparatively short entitlement for mothers (e.g., Uruguay), in others there is actually a comparatively generous duration of

Table 3. Gender gap indicator index in individual well-paid leave: Gap scores and country groupings.

\begin{tabular}{cl}
\hline Gender Gap Indicator Index & Countries \\
\hline 1 & Austria, Germany, Iceland, Norway, Portugal, South Africa, Sweden \\
3 & Finland, Spain \\
4 & China, Greece, Japan, Latvia, Lithuania, United Kingdom \\
5 & Belgium, Denmark, France, Luxembourg, Mexico, Netherlands, Quebec, Russia, Slovenia, \\
6 & South Korea, Uruguay \\
7 & Brazil, Cyprus, Estonia, Israel, Malta, Romania, Switzerland \\
8 & Chile, Czech Republic, Italy, Poland \\
9 & Croatia, Hungary, Slovakia \\
\hline
\end{tabular}


entitlement for fathers, but still a slightly longer one for mothers (e.g., Luxembourg).

Those countries scoring above 5 can be said to be explicitly maternalistic regimes, not generally recognising fathers as carers needing state support, with countries explicitly seeking to support mothers in this role. As such, relatively generous provision for mothers, such as in the case of Bulgaria, drives a high score on the gender gap indicator index. It could be argued that it is better for a parental team to find themselves in Bulgaria, with at least well-paid leave for one parent being available, rather than in a country which is gender equal, but which represents a race to the bottom in doing so in terms of the total support available to a family.

Table 4 alternatively presents the gender gap in wellpaid leave. Whilst some amount of well-paid leave is available to the family, mother or father in 42 of the 46 states under consideration, only seven of 46 have more than two months well-paid leave available for fathers. Some amount of well-paid leave is available to fathers in 37 of 46 states, but careful reading of Table 1 quickly reveals that this is often for a matter of days, in contrast to the individual leave available for mothers (in 41 of 46 states) which is usually available for some months. In addition to well-paid leave available as an individual entitlement for either mothers or fathers, leave can also have a family component. This is captured by the indicator in column (a) in Table 1 . This is leave that is in theory available to either parent, but in practice is most often taken by the mother, in all countries. Indeed, there is some indication that the gender gap is higher in countries with higher values on indicator in column (a) in Table 1. Only New Zealand has family entitlement (which is well-paid), without any individual component.

A weakness of the gender gap indicator index is that the same score can result when fathers are provided with shorter or longer periods of entitlement. As noted above, South Africa only scores a low gap as a result of there being no well-paid leave available to mothers at all. Figure 1 shows a scatter plot illustrating the correlation between a smaller gap and well-paid leave available (only) to fathers for longer time periods. All the countries with the lowest gender gap, with the exception of South Africa, offer fathers at least one month leave, and usually

Table 4. Prevalence of well-paid leave for fathers.

Well-paid leave

Number of states with well-paid leave of the 46 included in the analysis

Some amount of well-paid leave available to the family

Some amount of well-paid leave available to mothers only (typically at least 6 weeks)

Some amount of well-paid leave available to fathers only (this could only be a couple of days)

Some amount of well-paid leave available as a family entitlement (this could be in addition or not to individual leave)

At least one to two months of leave available to fathers only

More than two months available to fathers only

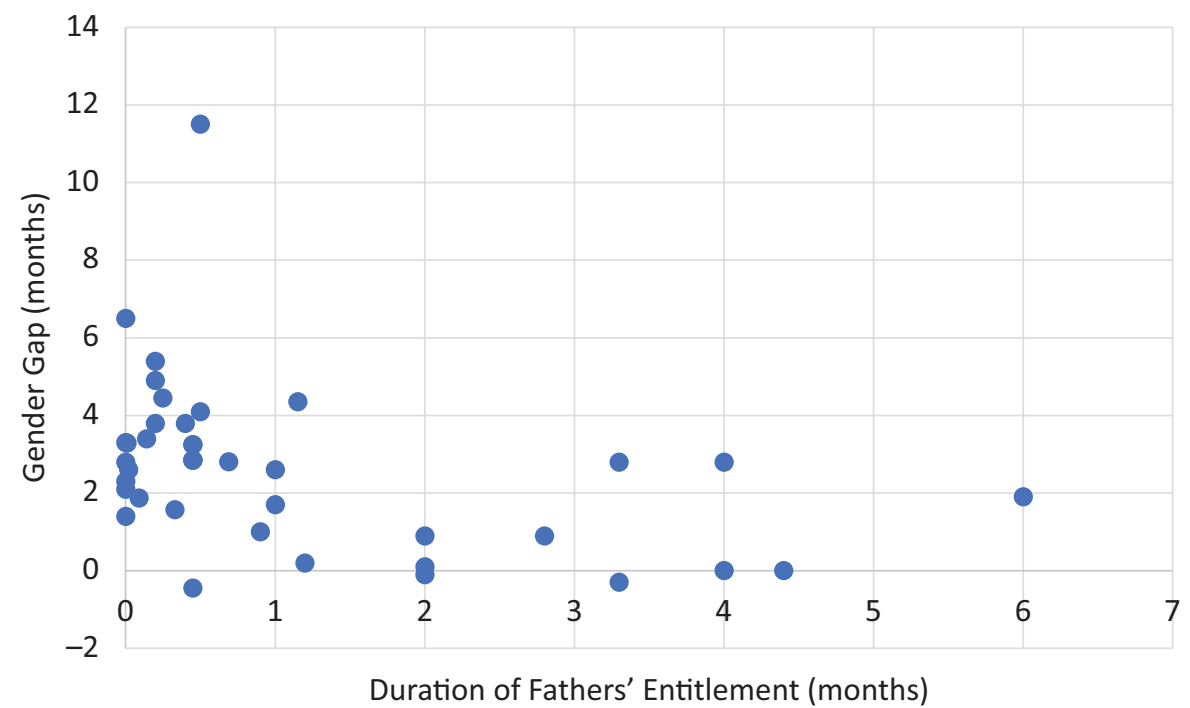

Figure 1. Gender gap (months) by fathers' individual entitlement to leave (months). 
more. As such, it is clear that it is important to focus on the gender gap indicator in the context of the length of leave provided to fathers. As such, there might be an argument to simply use the amount of well-paid leave for fathers as a measure for improved gender equality in benefit scope.

\section{Conclusion: Directions for Future Research}

Building on work such as that by Ray et al. (2010) this article illustrates that it can be relevant to compare not only parental leaves (e.g., European Institute for Gender Equality, 2020b), but all parenting related care leaves, including also maternity and paternity leaves, despite the difficulties of comparison of different categories of leave. To not do so is likely to lead to an under-estimation of the size of the gender gap in leave rights for many countries. It is not a new finding that there are gender differences in leave policy design, rather the contribution of this article is to quantify the extent of this gap for these 45 countries in 2020 by considering the range of leaves available to parents of infants.

A key aspect where a gender gap in leave policy rights exists is the different durations of gender specific individual entitlement (typically maternity and paternity). In many countries, paternity leave is around two weeks, and maternity leave is rarely shorter than 14 weeks. Thus, it becomes clear that a central issue for leave provision in many countries with respect to gender equality is men's unequal access to leave. The gender gap indicator allows us to understand that on average for these countries, this gap is between two to three months, and can extend to 11.5 months. It also becomes clear that it is possible to eliminate a gender gap in entitlement to individual leave rights, for example in Iceland and Norway. However, it is also important to consider the limitation of this gender gap indicator which does not include the periods of family entitlement which exist in addition to the individual entitlement, which are most frequently used by women, as also seen in Iceland and Norway.

The importance of the combination of high benefit level and longer leave entitlement has also been highlighted by the analysis. Less than four months is generally considered too short as a leave duration for mothers, yet only seven of the countries in the analysis offer fathers more than two months well-paid individual entitlement to leave. The duration of well-paid leave for fathers is by itself a useful and seemingly robust indicator of a more gender equal system of parenting related leave entitlement. Future studies might more directly assess the relationship between benefit level, entitlements, eligibility and use.

This work only reflects the gender gap for those who are eligible to parenting related leave, which may not be evenly distributed by gender (European Institute for Gender Equality, 2020b). The populations to which leave provisions may extend varies across countries most frequently by employment status. Scholars need to move beyond the scope of leave rights and consider eligibility, but it is nonetheless important to capture the gender inequalities in scope.

Finally, it is helpful to consider that mapping provision is not equivalent to mapping practice. Even in the case that we see the gender gap in entitlement more or less equalised, this does not guarantee that parents will take similar amounts of leave, but it is an important first step.

\section{Acknowledgments}

Thank you to the numerous country note authors in the International Network on Leave Policies and Research who have compiled all the data used in this article. Thank you also to the editors and the reviewers for helpful feedback on earlier drafts of this article.

\section{Conflict of Interests}

The author declares no conflict of interests.

\section{References}

Addabbo, T., Cardinali, V., Giovannini, D., \& Mazzucchelli, S. (2020). Italy country note. In A. Koslowski, S. Blum, I. Dobrotić, G. Kaufman, \& P. Moss (Eds.), International review of leave policies and research 2020 (pp. 338-352). Hagen: Fakultät für Kultur- und Sozialwissenschaften. http://dx.doi.org/10.18445/20200915131331-0

Andersen, S. (2018). Paternity leave and the motherhood penalty: New causal evidence. Journal of Marriage and Family, 80, 1125-1143.

Atkinson, J., O’Brien, M., \& Koslowski, A. (2020). United Kingdom country note. In A. Koslowski, S. Blum, I. Dobrotić, G. Kaufman, \& P. Moss (Eds.), International review of leave policies and research 2020 (pp. 583-600). Hagen: Fakultät für Kultur- und Sozialwissenschaften. http://dx.doi.org/10.18445/20200915131331-0

Bartel, A., Rossin-Slater, M., Ruhm, C., Stearns, J., \& Waldfogel, J. (2018). Paid family leave, fathers' leavetaking, and leave-sharing in dual-earner households. Journal of Policy Analysis and Management, 37(1), 10-37.

Boling, P. (2015). The politics of work-family policies. Comparing Japan, France, Germany and the United States. Cambridge: Cambridge University Press.

Bungum, B., \& Kvande, E. (2020). Norway country note. In A. Koslowski, S. Blum, I. Dobrotić, G. Kaufman, \& P. Moss (Eds.), International review of leave policies and research 2020 (pp. 444-455). Hagen: Fakultät für Kultur- und Sozialwissenschaften. http://dx.doi.org/ 10.18445/20200915-131331-0

Bünning, M. (2015). What happens after the 'daddy months'? Fathers' involvement in paid work, childcare, and housework after taking parental leave in Germany. European Sociological Review, 31(6), 738-748. 
Caracciolo di Torella, E. (2014). Brave new fathers for a brave new world? Fathers as caregivers in an evolving European Union. European Law Journal, 20(1), 88-106.

Castro-Garcia, C., \& Pazos-Moran, M. (2015). Parental leave policy and gender equality in Europe. Feminist Economics, 22(3), 51-73.

Ciccia, R., \& Verloo, M. (2012). Parental leave regulations and the persistence of the male breadwinner model: Using fuzzy-set ideal type analysis to assess gender equality in an enlarged Europe. Journal of European Social Policy, 22(5), 507-528.

Daly, M., \& Szelewa, D. (2020). Ireland country note. In A. Koslowski, S. Blum, I. Dobrotić, G. Kaufman, \& P. Moss (Eds.), International review of leave policies and research 2020 (pp. 322-331). Hagen: Fakultät für Kultur- und Sozialwissenschaften. http://dx.doi.org/ 10.18445/20200915-131331-0

Dearing, H. (2016). Gender equality in the division of work: How to assess European leave policies regarding their compliance with an ideal leave model. Journal of European Social Policy, 26(3), 234-247.

Digoix, M. (Ed.). (2020). Same-sex families and legal recognition in Europe. Cham: Springer International Publishing.

Dimitrova, E., Kotzeva, T., \& Ilieva, K. (2020). Bulgaria country note. In A. Koslowski, S. Blum, I. Dobrotić, G. Kaufman, \& P. Moss (Eds.), International review of leave policies and research 2020 (pp. 129-144). Hagen: Fakultät für Kultur- und Sozialwissenschaften. http://dx.doi.org/10.18445/20200915-131331-0

Dobrotić, I. (2020). Croatia country note. In A. Koslowski, S. Blum, I. Dobrotić, G. Kaufman, \& P. Moss (Eds.), International review of leave policies and research 2020 (pp. 194-204). Hagen: Fakultät für Kultur- und Sozialwissenschaften. http://dx.doi.org/ 10.18445/20200915-131331-0

Dobrotić, I., \& Blum, S. (2020). Inclusiveness of parentalleave benefits in twenty-one European countries: Measuring social and gender inequalities in leave eligibility. Social Politics, 27(3), 588-614.

Doucet, A., \& McKay, L. (2020). Fathering, parental leave, impacts, and gender equality: What/how are we measuring? International Journal of Sociology and Social Policy, 40(5/6), 441-463.

den Dulk, L., Yerkes, M., \& Peper, B. (2018). Work-family policies within the workplace. In G. B. Eydal \& T. Rostgaard (Eds.), Handbook of family policy (pp. 139-151). Cheltenham: Edward Elgar.

Duvander, A.-Z., \& Johansson, M. (2012). What are the effects of reforms promoting fathers' parental leave use? Journal of European Social Policy, 22(3), 319-330.

Duvander, A.-Z., \& Löfgren, N. (2020). Sweden country note. In A. Koslowski, S. Blum, I. Dobrotić, G. Kaufman, \& P. Moss (Eds.), International review of leave policies and research 2020 (pp. 555-566). Hagen: Fakultät für Kultur- und Sozialwissenschaften. http:// dx.doi.org/10.18445/20200915-131331-0

European Institute for Gender Equality. (2020a). Gender equality index 2020: Digitalisation and the future of work. Luxembourg: Publications Office of the European Union.

European Institute for Gender Equality. (2020b). Eligibility for parental leave in EU Member States. Luxembourg: Publications Office of the European Union.

European Institute for Gender Equality. (2021). Gender inequalities in care and consequences for the labour market. Luxembourg: Publications Office of the European Union.

Eydal, G. B., \& Rostgaard, T. (2016). Introduction. In G. B. Eydal \& T. Rostgaard (Eds.), Fatherhood in the nordic welfare states (pp. 1-20). Bristol: Policy Press.

Gábos, A., \& Makay, Z. (2020). Hungary country note. In A. Koslowski, S. Blum, I. Dobrotić, G. Kaufman, \& P. Moss (Eds.), International review of leave policies and research 2020 (pp. 303-312). Hagen: Fakultät für Kultur- und Sozialwissenschaften. http://dx.doi.org/ 10.18445/20200915-131331-0

Haas, L., \& Rostgaard, T. (2011). Fathers' rights to paid parental leave in the nordic countries: Consequences for the gendered division of leave. Community, Work \& Family, 14(2), 177-195.

Karu, M., \& Tremblay, D.-G. (2018). Fathers on parental leave: An analysis of rights and take-up in 29 countries. Community, Work \& Family, 21(3), 344-362.

Kaufman, G. (2020). Fixing parental leave: The six month solution. New York, NY: New York University Press.

Koslowski, A., Blum, S., Dobrotić, I., Kaufman, G., \& Moss, P. (Eds). (2020). International review of leave policies and research 2020. Hagen: Fakultät für Kultur- und Sozialwissenschaften. http://dx.doi.org/ 10.18445/20200915-131331-0

Koslowski, A., \& Duvander, A.-Z. (2018). Basic income: The potential for gendered empowerment. Social Inclusion, 6(4), 8-15.

Koslowski, A., \& Kadar-Satat, G. (2019). Fathers at work: Explaining the gaps between entitlement to leave and uptake. Community, Work \& Family, 22(2), 129-145.

Kurowska, A., Michoń, P., \& Godlewska-Bujok, B. (2020). Poland country note. In A. Koslowski, S. Blum, I. Dobrotić, G. Kaufman, \& P. Moss (Eds.), International review of leave policies and research 2020 (pp. 456-467). Hagen: Fakultät für Kultur- und Sozialwissenschaften. http://dx.doi.org/10.18445/20200915131331-0

Moss, P., Koslowski, A., \& Duvander, A.-Z. (2019). Introduction: Much work still to do. In P. Moss, A.-Z. Duvander \& A. Koslowski (Eds.), Parental leave and beyond. Recent international developments, current issues and future directions (pp. 1-17). Bristol: Policy Press.

Moss, P., \& O’Brien, M. (2019). United Kingdom: Leave policy and an attempt to take a new path. In P. Moss, A.-Z. Duvander, \& A. Koslowski (Eds.), Parental leave 
and beyond. Recent international developments, current issues and future directions (pp. 57-73). Bristol: Policy Press.

O'Brien, M. (2009). Fathers, parental leave policies and infant quality of life: International perspectives and policy impact. The Annals of the American Academy of Political and Social Science, 624(1), 190-213.

O’Brien, M., \& Wall, K. (Eds.). (2017). Comparative perspectives on work-life balance and gender equality: Fathers on leave alone. Cham: Springer International Publishing.

Olivetti, C., \& Petrongolo, B. (2017). The economic consequences of family policies: Lessons from a century of legislation in high-income countries. Journal of Economic Perspectives, 31(1), 205-230.

Pettigrew, R. (2020). Canadian employers' reaction and policy adaptation to the extended, 61-week parental leave. Canadian Studies in Population, 47, 97-109.

Pronzato, C. (2009). Return to work after childbirth: Does parental leave matter in Europe? Review of Economics of the Household, 7(4), 341-360.
Ray, R., Gornick, J., \& Schmitt, J. (2010). Who cares? Assessing generosity and gender equality in parental leave policy designs in 21 countries. Journal of European Social Policy, 20(3), 196-216.

Schober, P., Blum, S., Erler, D., \& Reimer, T. (2020). Germany country note. In A. Koslowski, S. Blum, I. Dobrotić, G. Kaufman, \& P. Moss (Eds.), International review of leave policies and research 2020 (pp. 274-288). Hagen: Fakultät für Kultur- und Sozialwissenschaften. http://dx.doi.org/10.18445/20200915131331-0

Thévenon, O. (2011). Family policies in OECD countries: A comparative analysis. Population and Development Review, 37, 57-87.

Wall, K., Correia, R. B., \& Leitão, M. (2020). Portugal country note. In A. Koslowski, S. Blum, I. Dobrotić, G. Kaufman, \& P. Moss (Eds.), International review of leave policies and research 2020 (pp. 468-483). Hagen: Fakultät für Kultur- und Sozialwissenschaften. http://dx.doi.org/10.18445/20200915-131331-0

\section{About the Author}

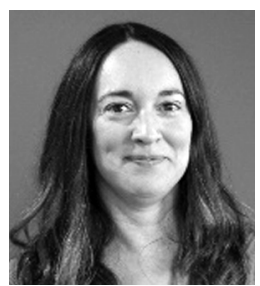

Alison Koslowski is Professor of Social Policy and Research Methods at the University of Edinburgh. She is also an Honorary Professor at University College London, based at the Thomas Coram Research Unit. Her research focuses on the connections between the labour market, care and gender equality. She co-edits the annual International Review of Leave Policies and Research. 